\title{
SUSCEPTIBILITY OF BEE LARVAE TO CHALKBROOD IN RELATION TO HYGIENIC BEHAVIOUR OF WORKER BEES IN COLONIES OF CHOSEN RACES OF HONEYBEE (APIS MELLIFERA)
}

\author{
Beata Panasiuk* \\ Małgorzata Bieńkowska \\ Dariusz Gerula \\ Paweł Węgrzynowicz \\ Research Institute of Horticulture, Apiculture Division, \\ Kazimierska 2, 24-100 Puławy, Poland \\ *corresponding author: beata.panasiuk@man.pulawy.pl \\ Received 25 August 2013; accepted 03 April 2014
}

\begin{abstract}
A bstract
The susceptibility of bee larvae to Ascosphaera apis infestation and the hygienic behaviour of worker bees in relation to $A$. apis infected and freeze-killed brood were evaluated in three races of bees: Apis mellifera carnica, Apis mellifera caucasica, and Apis mellifera mellifera. Experimental bee colonies were evaluated in field conditions during the three beekeeping seasons. The lowest percentage of infected larvae was observed in car GR1 and mel A colonies ( $8.5 \%$ and $15 \%$, respectively) and the highest in car Mr and cau $\mathrm{P}$ colonies ( $21 \%$ and $24.3 \%$, respectively). Bees in the car GR 1 and mel A colonies removed mummified brood in a shorter period of time (6.5 and 7.1 days on average, respectively) than car Mr and cau P colonies (above 8 days). Bees in the mel A and car GR1 colonies cleaned significantly more cells with freeze-killed brood within 24 and 48 hours (above $70 \%$ and $80 \%$ on average, respectively) than car Mr and cau $\mathrm{P}$ colonies (on average 10 $20 \%$ lower cleaning rate). A low correlation coefficient was found for the susceptibility of larvae to $A$. apis infection and hygienic behaviour.
\end{abstract}

Keywords: Ascosphaera apis, freeze-killed brood, hygienic behaviour, larvae susceptibility.

\section{INTRODUCTION}

Honey bee (Apis mellifera) diseases are a major problem in colony management. Pathogens and diseases can negatively affect colony growth and production, resulting in economic losses. Effective treatments are lacking for some diseases, and chalkbrood is a disease for which some alternative methods should be developed for control.

Chalkbrood is a common fungal disease caused by Ascosphaera apis (Spiltoir, 1955). The disease causes death of bee larvae of any caste and is transmitted within a colony by the nurse bees feeding larvae with food contaminated with $A$. apis spores. According to Bailey (1981), 3 to 4-day-old larvae are the most susceptible, whereas others have found that younger larvae are also susceptible (Gilliam et al., 1978). Nevertheless, Jensen et al. (2009) showed that, in 5-day-old larvae, $A$. apis spores have limited time in the gut for germination and tissue penetration. Enzymes produced by $A$. apis enable the fungi to damage peritrophic membranes of the gut and grow in the larval body cavity (Theantana and Chantawannakul, 2008). Field recognition of the disease is based on visual identification of mummified brood. Clinical symptoms of chalkbrood appear for short periods, mostly in cold and damp weather (Aronstein and Murray, 2010). Chilling of the brood during the development period increases the number of diseased larvae (Vojvodic et al., 2011). Different methods have been used for larval inoculation with $A$. apis in studies of the disease and the selection of bees resistant to chalkbrood. In some studies, larvae were fed with sugar-honey-pollen candy inoculated with spores of $A$. apis (Milne, 1983; Taber, 1986; Taber and Gilliam, 1987; Bieńkowska and Konopacka, 1999; Panasiuk et al., 2008). Another method was spraying the comb with larvae using a suspension of mummies in sugar syrup (Gilliam et al., 1983; Koenig et al., 1987; 
Chorbiński, 2004) or water (Carrera et al., 1987). However, these methods resulted in irregular larvae infection (Gliński, 1981; Carrera et al., 1987; Puerta et al., 1990; Panasiuk et al., 2008). According to Flores et al. (2004), larvae inoculation was higher after spraying water with spores over the comb or feeding colonies a spore-pollen mixture than feeding colonies sugar syrup containing spores.

Honey bees have developed colony level behaviours to control or eliminate pathogens (Cremer et al., 2007). The hygienic behaviour of honey bees is a genetically determined trait and a known mechanism for disease resistance. Hygiene involves the detection of diseased or dead brood in capped cells, and uncapping and removing them from the nest (Rothenbuhler and Thomson, 1956; Rothenbuhler, 1964; Milne, 1985). This behaviour eliminates the source of infection and limits disease transmission within the colony. The hygienic behaviour of bees was tested using different methods of brood killing, including freeze-killed and pin-killed brood (Spivak and Downey, 1998; Newton and Ostasiewski, 1986). Differences in the hygienic behaviours of bees of different races (bee subspecies) have been widely described. Hygienic bees remove a greater number of dead brood compared to non-hygienic within the same timeframe (Spivak and Gilliam, 1993; Büchler, 1996; Kefuss et al., 1996; Spivak and Downey, 1998; Arathi and Spivak, 2001; Panasiuk et al., 2008; Bąk et al., 2010). Phenotypic selection leads to populations with higher proportions of hygienic bees (Rothenbuhler, 1964; Heath, 1982; Büchler, 1996; Palacio et al., 2000). However, bees bred for hygienic behaviour against brood diseases detect and remove less Varroa mite-infested pupae than bees bred for specific hygienic behaviours against $V$. destructor or other mechanisms of resistance against mites (Ibrahim and Spivak, 2006; Danka et al., 2013).

We investigated the susceptibility of honey bee larvae from different races (Apis mellifera carnica, Apis mellifera caucasica, and Apis mellifera mellifera) to chalkbrood disease in colonies kept in field conditions. We also evaluated the hygienic behaviour of adult bees in the same colonies.

\section{MATERIAL AND METHODS}

The research was conducted at the Department of Bee Breeding in the Research Institute of Horticulture, Apiculture Division, in Puławy. The experiment was repeated in July and August during three seasons, from 2010 to 2012, after the main honey flow. In
2010, two races of bees were used: $A$. m. carnica (lines car GR1 and car Mr) and A. m. caucasica (line cau $\mathrm{P}$ ). In the subsequent seasons, $A$. m. mellifera (line mel A) was introduced into the experiment. These three races of bees are currently used in Polish national breeding programs and are kept by commercial beekeepers. The race of bees taken from breeding colonies was confirmed based on automatic measurements of forewing venation using DrawWing computer software (Tofilski, 2004; Gerula et al., 2009). Each year, new colonies were generated with commercial queens and bees of the same breed. The initial bee colonies were in good condition with no symptoms of any disease.

The experimental colonies were kept in nucleus hives with six frames measuring $220 \times 180 \mathrm{~mm}$. The colonies were tested in the same apiary and managed in the same way. To obtain combs with brood of the same age, the queens were caged using queen excluders for 48 hours to lay eggs. Experimental hives were equipped with entrances with queen excluder nets to prevent housekeeping bees from removing chalkbrood mummies from the hive. The entire experiment was conducted during the period of moderate honey flow.

The colonies were fed with pollen loads, icing sugar, and honey candy (in 2:1:1 ratio) inoculated with spores of $A$. apis to evaluate the susceptibility of young bee larvae to chalkbrood. The mixture was prepared for inoculation using mummified brood (5 mummies per $1000 \mathrm{~g}$ of candy crushed and stirred in $50 \mathrm{~mL}$ of distillate water) (Taber, 1986; Taber and Gilliam, 1987; Panasiuk et al., 2008). Mummies originated from bee colonies naturally infected by $A$. apis that exhibited symptoms of the disease. The feeding started when larvae on an experimental comb were 2 - 3 days old. To 80 g portion of candy, 2 $\mathrm{mL}$ of the inoculation mixture was added, thoroughly mixed, and put on the top bars in the colonies. All uncapped brood were removed from the colonies before experimental feeding to avoid their inoculation. Bees ate the given food within 2 days. The capped brood cells on the experimental frame were counted in each colony immediately after capping. The mummies of diseased brood were observed in entrance boxes and on hive boards. The mummies were collected from the hives each day, starting from the second day after brood capping. The observations terminated after all brood were either cleaned or emerged from the cells. The number of mummies collected from entrance boxes and hive boards was used to determine the percentage of brood infected with $A$. apis. Susceptibility was calculated as the sum 
of mummies removed by bees and collected from each colony in relation to capped brood cells.

The hygienic behaviour of bees based on cleaning freeze-killed brood was also evaluated in experimental colonies. The hygienic behaviour test was performed when the experiment with $A$. apis-inoculated brood was finished in all colonies. A brood comb from a standard carniolan colony was put in the refrigerator at $-18^{\circ} \mathrm{C}$ for 20 hours. The comb was then cut into small pieces and left at room temperature to thaw. Each experimental colony received a piece of comb with roughly 100-150 brood cells inserted in the hole cut in the centre of the middle nest comb.

The number of clean cells was counted 24 and 48 hours after introducing the comb pieces into the colonies and the percentage of brood removal calculated.

ANOVA was used for the statistical analysis. The percentage of cleaned cells was transferred using arcsine transformation and compared with Tukey's HSD test. The correlation between the percentage of clean cells with freeze-killed brood and percentage of mummified brood was determined using Pearson's correlation coefficient.

\section{RESULTS}

Significant differences in the susceptibility of brood to $A$. apis were observed between bee lines in different years. In 2010, carGR1 and car Mr bees had the same percentage of infected larvae, whereas cau $P$ had significantly greater rates of infection. In the successive season, although differences were still found in the percentage of infected larvae, they were not significant. Mel $\mathrm{A}$ and cau $\mathrm{P}$ colonies had moderate percentages of mummified brood. In 2012, the mel A, car GR1, and cau P colonies had significantly lower rates of infected larvae compared to $\operatorname{car} \mathrm{Mr}$ (Tab.1). In 2010 and 2012, the average percentage of infected larvae was significantly lower than the average in 2011 (Tab. 1).

When comparing the tested bee populations, the lowest percentage of infected larvae, regardless of the year of research, was found in car GR1 bees. Cau P colonies had the highest percentage of mummified brood, whereas mel $A$ and car Mr reached moderate percentages of infected larvae (Tab.1).

Percentage of brood infected with Ascosphaera apis

\begin{tabular}{|c|c|c|c|c|c|c|}
\hline $\begin{array}{l}\text { Honey bee } \\
\text { race and line }\end{array}$ & Year & $\begin{array}{c}\text { No. of } \\
\text { colonies }\end{array}$ & $\begin{array}{l}\text { Average no. of } \\
\text { sealed brood } \\
\text { cells }\end{array}$ & $\begin{array}{l}\text { Average } \\
\text { no. of } \\
\text { removed } \\
\text { mummies }\end{array}$ & $\begin{array}{l}\text { Avera } \\
\text { of rem } \\
\text { mumr }\end{array}$ & $\begin{array}{l}\text { ye } \% \\
\text { oved } \\
\text { nies }\end{array}$ \\
\hline A. m. carnica GR1 & \multirow{3}{*}{2010} & 5 & 438.4 & 28.6 & $9.2 \mathrm{a}$ & \multirow{3}{*}{ 15.0a } \\
\hline A. m. carnica Mr & & 9 & 1016.3 & 106.1 & 9.3a & \\
\hline A. m. caucasica $\mathrm{P}$ & & 6 & 759.7 & 207.7 & 28.3b & \\
\hline A. m. carnica GR1 & \multirow{4}{*}{2011} & 5 & 245.6 & 23.2 & $10.4 a$ & \multirow{4}{*}{ 24.9a } \\
\hline A. m. carnica Мг & & 5 & 159.2 & 56.2 & $37.7 a$ & \\
\hline A. m. caucasica $\mathrm{P}$ & & 5 & 274.8 & 59.8 & 28.0a & \\
\hline A. m. mellifera $\mathrm{A}$ & & 4 & 220.5 & 53.0 & $25.4 a$ & \\
\hline A. m. carnica GR1 & \multirow{4}{*}{2012} & 5 & 984.2 & 57.0 & $5.8 a$ & \multirow{4}{*}{$13.4 a$} \\
\hline A. m. carnica Mr & & 5 & 662.6 & 161.4 & 25.6b & \\
\hline A. m. caucasica $\mathrm{P}$ & & 5 & 850.6 & 123.6 & $15.8 a$ & \\
\hline A. m. mellifera $\mathrm{A}$ & & 4 & 747.2 & 30.2 & $4.5 a$ & \\
\hline A. m. carnica GR1 & \multirow{4}{*}{$\begin{array}{l}2010 \\
-2012^{*}\end{array}$} & 15 & 556.1 & 36.3 & $8.5 \mathrm{~A}$ & \\
\hline A. m. carnica Mr & & 19 & 612.7 & 107.9 & $21.1 \mathrm{AB}$ & \\
\hline A. m. caucasica $\mathrm{P}$ & & 16 & 628.4 & 130,3 & $24.3 B$ & \\
\hline A. m. mellifera $\mathrm{A}$ & & 8 & 483.8 & 41.6 & $14.9 A B$ & \\
\hline
\end{tabular}

$a, b-p \leq 0.05$ within a year or between years

$A, B-p \leq 0.05$ between colonies of different races and lines

* A. m. mellifera: 2011 - 2012 
Time required to remove mummies of brood infected with Ascosphaera apis

\begin{tabular}{|c|c|c|c|c|c|}
\hline $\begin{array}{l}\text { Honey bee } \\
\text { race and line }\end{array}$ & Year & $\begin{array}{l}\text { No. of } \\
\text { colonies }\end{array}$ & $\begin{array}{c}\text { Average no. } \\
\text { of cleaning } \\
\text { days }\end{array}$ & $\begin{array}{c}\text { Range, } \\
\text { days }\end{array}$ & $\begin{array}{c}\text { Average no. of } \\
\text { cleaning days } \\
\text { in the year }\end{array}$ \\
\hline
\end{tabular}

\begin{tabular}{|c|c|c|c|c|c|}
\hline A. m. carnica GR1 & \multirow{3}{*}{2010} & 5 & $5.8 a$ & $5-7$ & \multirow{3}{*}{ 7.7a } \\
\hline A. m. carnica Mr & & 9 & $7.4 \mathrm{~b}$ & $5-10$ & \\
\hline A. m. caucasica $P$ & & 6 & $9.7 b$ & $8-10$ & \\
\hline A. m. carnica GR1 & \multirow{4}{*}{2011} & 5 & $6.8 a$ & $6-8$ & \multirow{4}{*}{$7.5 a$} \\
\hline A. m. carnica Mr & & 5 & $8.0 a$ & 8 & \\
\hline A. m. caucasica $\mathrm{P}$ & & 5 & 7.8a & $7-8$ & \\
\hline A. m. mellifera $\mathrm{A}$ & & 4 & $7.2 a$ & $6-8$ & \\
\hline A. m. carnica GR1 & \multirow{4}{*}{2012} & 5 & $7.0 \mathrm{a}$ & $6-8$ & \multirow{4}{*}{8.1} \\
\hline A. m. carnica Mr & & 5 & $10.0 b$ & $8-11$ & \\
\hline A. m. caucasica $\mathrm{P}$ & & 5 & $8.4 \mathrm{~b}$ & $7-11$ & \\
\hline A. m. mellifera $\mathrm{A}$ & & 4 & $7.0 a$ & 7 & \\
\hline A. m. carnica GR1 & \multirow{4}{*}{$\begin{array}{c}2010 \\
-2012^{\star}\end{array}$} & 15 & $6.5 \mathrm{~A}$ & $5-8$ & \\
\hline A. m. carnica Mr & & 19 & $8.3 B$ & $5-11$ & \\
\hline A. m. caucasica $\mathrm{P}$ & & 16 & 8.7B & $7-11$ & \\
\hline A. m. mellifera $\mathrm{A}$ & & 8 & $7.1 \mathrm{~A}$ & $6-8$ & \\
\hline
\end{tabular}

Bees detected diseased brood under the caps and removed dead brood from the cells. Car GR1 bees removed dead brood in the shortest amount of time, whereas mel A bees required slightly longer. Car $\mathrm{Mr}$ and cau $\mathrm{P}$ bees took significantly longer to clean infected brood. However, cleaning time did not differ significantly between tested bee lines in 2011 (Tab. 2).

The bees required 7.5 to 8.1 days on average to remove dead mummies during the course of the observed years. The shortest time period was recorded in 2011 and the longest in 2012, but the differences were not significant. Regardless of the year, car GR1 bees on average removed mummies from comb cells significantly faster than car Mr and cau $P$ colonies, which took the longest (Tab. 2).

Car GR1 bees in 2010 and car GR1 and mel A bees in 2012 cleaned the highest percentage of cells at both observation time points, but the differences from car Mr and cau $\mathrm{P}$ were not significant. In 2011 the highest rate of removal was observed in mel A colonies after the first 24 hours. Car GR1 bees removed dead brood slightly slower, with car Mr being significantly slower (Tab. 3). The same tendency was observed for the measurement at 48 hours but the differences were not significant. During the first day after frozen brood introduction, bees removed more than $60 \%$ of cells on average (from above $40 \%$ to $>90 \%$ ). During the subsequent 24 hours, bees cleaned an additional approximate $10 \%$ of the initial number of cells. The highest cleaning rate was observed in 2011 , and the lowest in 2010, regardless of line being observed (Tab. 3). The mel $A$ and carGR1 bees cleaned the most freezekilled brood, and carMr removed the fewest when all experimental years were analysed together (Tab. 3). The observation of both fast $A$. apis-infected mummy removal and fast freeze-killed brood cleaning in the car GR1 and mel A colonies indicated high hygienic behaviour among these bee populations. A significant correlation was found between removing freeze-killed brood from the colonies after 24 and 48 hours and actively removing chalkbrood mummies from colonies ( $r=0.56$ and $r=0.66$, respectively, $\mathrm{p}<0.00$ ). 
Table 3.

Percentage of freeze-killed brood removed after 24 and 48 hours

\begin{tabular}{|c|c|c|c|c|c|c|}
\hline \multirow{3}{*}{$\begin{array}{l}\text { Honey bee } \\
\text { race and line }\end{array}$} & \multirow{3}{*}{ Year } & \multirow{3}{*}{$\begin{array}{l}\text { No. of } \\
\text { colonies }\end{array}$} & \multicolumn{4}{|c|}{ Average $\%$ of freeze-killed brood removed } \\
\hline & & & \multicolumn{2}{|c|}{$\begin{array}{c}\text { between bee lines } \\
\text { within a year }\end{array}$} & \multicolumn{2}{|c|}{ between years } \\
\hline & & & 24 hours & 48 hours & 24 hours & 48 hours \\
\hline A. m. carnica GR1 & \multirow{3}{*}{2010} & 5 & $67.1 a$ & $67.3 a$ & \multirow{3}{*}{ 49.8а } & \multirow{3}{*}{$54.7 a$} \\
\hline A. m. carnica Mr & & 9 & $45.5 a$ & $52.3 a$ & & \\
\hline A. m. caucasica $P$ & & 6 & 41.9a & 47.9a & & \\
\hline A. m. carnica GR1 & \multirow{4}{*}{2011} & 5 & $85.6 b$ & $96.6 a$ & \multirow{4}{*}{$81.2 b$} & \multirow{4}{*}{$94.6 c$} \\
\hline A. m. carnica Мr & & 4 & $62.3 a$ & 88.0a & & \\
\hline A. m. caucasica $\mathrm{P}$ & & 5 & $84.4 b$ & $95.8 a$ & & \\
\hline A. m. mellifera A & & 4 & 93.9b & $100 a$ & & \\
\hline A. m. carnica GR1 & \multirow{4}{*}{2012} & 5 & $64.0 a$ & $87.7 a$ & \multirow{4}{*}{$56.6 a$} & \multirow{4}{*}{$74.8 \mathrm{~b}$} \\
\hline A. m. carnica Mr & & 5 & $48.2 a$ & $65.8 a$ & & \\
\hline A. m. caucasica $\mathrm{P}$ & & 5 & 51.8a & 71.4a & & \\
\hline A. m. mellifera $\mathrm{A}$ & & 4 & $67.0 a$ & $74.3 a$ & & \\
\hline A. m. carnica GR1 & \multirow{4}{*}{$\begin{array}{l}2010 \\
-2012^{\star}\end{array}$} & 15 & $72.2 \mathrm{BC}$ & 83.5B & \multirow{4}{*}{61.7} & \multirow{4}{*}{70.2} \\
\hline A. m. carnica Mr & & 17 & $50.0 \mathrm{~A}$ & $63.9 A$ & & \\
\hline A. m. caucasica $\mathrm{P}$ & & 16 & 58.3AB & $70.2 A B$ & & \\
\hline A. m. mellifera $\mathrm{A}$ & & 8 & $76.8 C$ & 85.3AB & & \\
\hline
\end{tabular}

$a, b-p \leq 0.05$ within a year or between years

$A, B, C-p \leq 0.05$ between colonies of different races and lines

* A. m. mellifera: 2011 - 2012

\section{DISCUSSION}

Several methods of killing brood have been used to evaluate hygienic behaviour in honey bees. Panasiuk et al. (2008) reported that freeze-killed and $A$. apis spore-inoculated brood was removed more slowly, but the dynamics of removing these brood were similar, whereas pin-killed brood were removed faster and during the first 2 days after killing. Therefore, we used only $A$. apis inoculation and freeze-killed methods to address hygienic behaviour in our research.

The study was performed directly in bee colonies in field conditions. We reached an inoculation rate of 13.5 - $25 \%$ of larvae on the basis of the number of mummies removed relative to the number of capped brood cells. Carrera et al. (1987) found that 2 - 3\% of larvae exhibited disease symptoms 8 days after spray inoculation using a suspension of mummies in water. Larvae mummification was $>90 \%$ when spraying water with spores over comb and $86 \%$ when colonies were fed a spore-pollen mixture in the study by Flores et al. (2004), but the authors also chilled brood to increase the effects of the disease. A much lower mummification rate (60\%) was achieved after feeding colonies sugar syrup containing spores.

Some attempts at larval infection with $A$. apis failed for Carrera et al. (1987) because workers removed almost all of the treated brood from cells. In addition, Jensen et al. (2009) reported that many larvae could have died and been removed from cells before sealing them. Thus, the final number of removed mummies in our experiment may vary in accordance with the real infection level. We did not observe larvae before capping, but our research was finished when all cells on the observed comb were empty. During the first year of evaluation, bees of both $A$. m. carnica lines reached almost the same average percentage of infected larvae, but the initial numbers of capped brood cells were different. In the following 2 years, the difference in the number of capped brood cells was about $25 \%$ higher in car GR1, but the average percentage of infected larvae 
was 3.5 times higher in car Mr than in car GR1 in 2011 and almost 4.5 times higher in 2012. The rate of brood infection could have been affected by the different number of larvae on the experimental comb. The correlation calculated between the initial number of cells with capped brood and the percentage of removed mummies was $r=-0.4$ $(p<0.05)$, which indicates a greater number of cells negatively affected the level of infection.

Car GR1 bees had the lowest percentage of mummified brood and removed mummies in the shortest amount of time. A similar level of mummification and removal time was observed in mel $A$ colonies. This result was expected as car GR1 bees were selected for increased hygienic behaviour against $A$. apis diseased brood. Thus, $A$. m. mellifera (mel A) may have a higher natural resistance to disease.

Our data indicate differences in the susceptibility of larvae to $A$. apis among the analysed honey bee populations. Jensen et al. (2009) reported higher susceptibility and mortality of larvae form $A$. m. caucasica and carnica colonies compared to ligustica colonies. In the present study, cau P larvae were significantly more susceptible to infection than the other lines. Several factors could have influenced the results of our experiment: the tested colonies may have been affected by a lower temperature in the nest, and the regular colony status may have been interrupted when brood and food stores were removed before feeding inoculated candy. The tendency for a low rate of $A$. apis brood infection in car GR1 and mel A colonies may indicate genetic mechanisms of resistance in these subspecies.

Hygienic behaviour may be a mechanism of disease resistance in bees. In our experiment we took combs with brood of the same age from a $A$. m. carnica bee colony. This avoided a possible effect of the race of killed brood on the rate of cell cleaning. Also, Spivak and Downey (1998) found that the origin of the frozen section of brood plays no role in the hygiene behaviour of the host colony.

A negative correlation was found between colonies that quickly removed freeze-killed brood and the development of chalkbrood disease (Gilliam et al., 1988). However, we did not find a correlation between the hygienic behaviour of bees and susceptibility of larvae to $A$. apis. We observed a significant correlation between the removal of freezekilled brood from colonies after 24 and 48 hours and the removal of chalkbrood mummies. Our findings correspond to those of Boecking and Drescher (1992), who reported a correlation between the removal of frozen brood and brood artificially infected with Varroa females. These results corroborate that hygienic bees remove damaged brood regardless of the cause of damage.

The car GR1 colony in the first year of the experiment and mel A colonies in the two successive seasons had the highest percentage of freeze-killed brood removed after 24 and 48 hours. Similarly, Bąk et al. (2010) found, in small mating hives, that A. $m$. mellifera bees recognize and uncap dead brood earlier than $A$. m. caucasica, A. m. carnica, and $A$. m. carnica hybrid bees. However, when the authors analysed the mean percentage of cells cleaned within particular groups 24 hours after introduction into the colonies, car Dobra bees cleaned slightly more cells than $A$. m. mellifera bees. The same study reported $9.9 \%$ and $9.6 \%$ clean brood cells in car Dobra and mel Augustowska, respectively, 24 hours after the introduction of freeze-killed brood, which is much less than our observation. The difference may be due to our colonies being stronger with a larger population of bees of an age when they perform removal, a function identified by Krivtsova (2001); mid-Russian bees kept in strong colonies removed $87.5 \%$ of the frozen brood within 24 hours of the experiment. Koenig et al. (1987) also proposed that the ability to clean cells depends on the strength of the bee colonies.

\section{CONCLUSIONS}

Larvae of the car GR1 and mel A have lower susceptibility to $A$. apis than car Mr and cau P.

Colonies of car GR1 and mel A cleaned a higher percentage of freeze-killed brood than cau $\mathrm{P}$ and car Mr.

A low correlation coefficient was found for the susceptibility of larvae to $A$. apis infection and hygienic behaviour, which may indicate a lack of relationship between these traits.

\section{REFERENCES}

Arathi H. S., Spivak M. (2001) Influence of colony genotypic composition on the performance of hygienic behaviour in the honeybee, Apis mellifera L. Animal Behaviour 62: 57-66.

Aronstein K. A., Murray K. D. (2010) Chalkbrood disease in honey bees. Journal of Invertebrate Pathology 103: 2029. DOl: 10.1016/j.jip.2009.06.018 


\section{J. APRC. SCLI. VOL. 58 NO. 12014}

Bailey L. 1981. Honey Bee Pathology. Academic Press. London, UK. 124 pp.

Bąk B., Wilde J., Siuda M. (2010) Comparison of hygienic behaviour between five honey bee breeding lines. Journal of Apicultural Science 54(2): 17-24.

Bieńkowska M., Konopacka Z. (1999) Porównanie metod oceny porażenia rodzin pszczelich przez grzybicę wapienną. Pszczelnicze Zeszyty Naukowe (43): 93-106.

Boecking O., Dresher W. (1992) The removal response of Apis mellifera L. colonies to brood in wax and plastic cells after experimental and natural infestation with Varroa jacobsoni Oud. and freeze-killed brood. Experimental and Applied Acarology 16: 321-329.

Büchler R. (1 996) Selektion auf Bruthygiene in der Kirchhainer Population. Apidologie 27(4): 280.

Carrera P., Sommaragua A., Vailiti G. (1987) The development of Ascosphaera apis within larvae of Apis mellifera ligustica. Journal of Apicultural Research 26(1): 59-63.

Chorbiński P. (2004) The development of the infection of Apis mellifera larvae by Ascosphaera apis. Electronic Journal of Polish Agricultural Universities, Veterinary Medicine 7(2). Available at: http://www.ejpau.media.pl/ volume7/issue2/veterinary/art-03.html

Cremer S., Armitage S., Schmid-Hempel P. (2007) Social immunity. Current Biology 17: 693-702. DOl: 10.1016/j. cub.2007.06.008

Danka R. G., Harris J. W., Villa J. D., Dodds G. E. (2013) Varying congruence of hygienic responses to Varroa destructor and freeze-killed brood among different types of honeybees. Apidologie 44: 447-457. DOl: 10.1007/ s13592-013-0195-8

Flores J. M., Gutiérrez I., Puerta F. (2004) A comparison of methods to experimentally induce chalkbrood disease in honey bees. Spanish Journal of Agricultural Research 2: 79-83.

Gerula D., Tofilski A., Węgrzynowicz P., Skowronek W. (2009) Computer-assisted discrimination of honeybee subspecies used for breeding in Poland. Journal of Apicultural Science 53(2): 105-114.

Gilliam M., Taber S., Rose J. B. (1978) Chalkbrood of honeybees, Apis mellifera L, a progress report. Apidologie 9(1): 75-89.
Gilliam M., Taber III S., Richardson G.V. (1 983) Hygienic behaviour of honey bees in relation to chalkbrood disease. Apidologie 14(1): 29-39.

Gilliam M., Taber S., Lorenz B. J., Prest D. B. (1988) Factors affecting development of chalkbrood disease in colonies of honey bees, Apis mellifera, fed pollen contaminated with Ascosphaera apis. Journal of Invertebrate Pathology 52: 314-325.

Gliński Z. (1981) Studies on the effect of the fungus Ascosphaera apis on larvae of honey bee, Apis mellifera L. Polskie Archiwum Weterynaryjne 23(1): 9-16.

Heath L. A. F. (1982) Development of chalk brood in honey bee colony: a review. Bee World 63: 1 19-135.

Ibrahim A., Spivak M. (2006) The relationship between hygienic behaviour and suppression of mite reproduction as honey bee (Apis mellifera) mechanisms of resistance to Varroa destructor. Apidologie 37: 31 -40. DOl: 10.1051/ apido:2005052

Jensen A. B., Pedersen B. V., Eilenberg J. (2009) Differential susceptibility across honey bee colonies in larval chalkbrood resistance. Apidology 40: 524-534. DOl: 10.1051/apido/2009029

Kefuss J., Taber S., Vanpoucke J., Rey F. (1996) A Practical Method to Test for Disease Resistance in Honey Bees. American Bee Journal 136(1): 31-32.

Koenig J. P., Boush G. M., Erickson E. H. (1987) Effects of spore introduction and ratio of adult bees to brood on chalkbrood disease in honeybee colonies. Journal of Apicultural Research 26(3): 191-195.

Krivtsova L. S. (2001) The hygienic behaviours of bees as the selection characteristic. In: Materiały z XXXVIII Naukowej Konferencji Pszczelarskiej, Puławy. 13-14 March 2001: 116-117.

Milne C. P. Jr. (1983) Honey bee (Hymenoptera: Apidae) hygienic behaviour and resistance to chalkbrood. Annales of the Entomological Society of America 76: 384-387.

Milne C. P. Jr. (1985) Laboratory tests of honey bee hygienic behaviour and resistance to European foulbrood. American Bee Journal 125: 578-280. 
Newton D. C., Ostasiewski N. L. (1986) A simplified bioassay for behavioural resistance to American foulbrood in honey bees (Apis mellifera L.). American Bee Journal 126: 278-281.

Palacio M. A., Figini E. E., Ruffinengo S. R., Rodriguez E. M., Del Hoyo M. L., Bedascarrasbure E. L. (2000) Changes in population of Apis mellifera L. selected for hygienic behaviour and its relation to disease tolerance. Apidologie 31(4): 471-478. DOl: 10.1051/apido:2000139

Panasiuk B., Skowronek W., Bieńkowska M. (2008) Influence of genotype and method of brood killing on brood removal rate in honey bee. Journal of Apicultural Science 52(2): 55-65.

Puerta S., Flores Serrano J. M., Pollen Martinez P., Puerto Ruiz M., Pedilla Alvarez F. (1990) Effect of inoculum dosage on the incidence of chalk brood disease in Apis mellifera and notes on its development. Revista Iberoamericana Micologia 7: 11-14.

Rothenbuhler W. C. (1964) Behaviour genetics of nest cleaning in honeybees. I. Responses of four inbred lines to disease killed brood. Animal Behaviour 12: 578-583.

Rothenbuhler W. C., Thompson V. C. (1956) Resistance to American foulbrood in honey bees. I. Differential survival of larvae of different genetic lines. Journal of Economic Entomology 49: 470-475.

Spiltoir C. F. (1955) Life cycle of Ascosphaera apis (Pericystis apis). American Journal of Botany 42(6): 501-508.
Spivak M., Downey D. L. (1998) Field assays for hygienic behaviour in honey bees (Apidae: Hymenoptera). Journal of Economic Entomology 91: 64-70.

Spivak M., Gilliam M. (1993) Facultative expression of hygienic behaviour of honey bees in in relation to disease resistance. Journal of Apicultural Research 32(3-4): 147157.

Taber III S. (1986) Breeding bees resistant to chalkbrood disease. American Bee Journal 126(12): 823-825.

Taber III S., Gilliam M. (1987) Test for resistance to chalkbrood disease, Ascosphaera apis, of honeybees. In: The XXXIst International Congress of Apiculture. Warsaw, Poland. 19-25 August 1987. Apimondia Publishing House. Bucharest, Romania: 145-148.

Theantana T., Chantawannakul P. (2008) Protease and B-N acetylglucosaminidase of honey bee chalkbrood pathogen Ascosphaera apis. Journal of Apicultural Research 47 (1): 68-76.

Tofilski A. (2004) DrawWing, a program for numeral description of insect wings. Journal of Insect Science 4: 1 -5.

Vojvodic S., Jensen A. B., James R. R., Boomsma J. J., Eilenberg J. (2011) Temperature dependent virulence of obligate and facultative fungal pathogens of honey bee brood. Veterinary Microbiology 149: 200-205. DOl: 10.1016j.vetmic.2010.10.001 